\title{
СОАЕРЖАНИЕ
}

\section{НАУЧНЫЕ ПУБАИКАЦИИ}

\section{В. А. Азюба, А. В. Есаулова, И. Н. Чухирь, А. Г. Зеленский}

Характеристика растений риса, в связи с генами, контроммирующими

структуру ^иста

Ю. В. Ткаченко, А. Г. Зеленский, Г. А. Зеленский

Сравнительная оценка сортов и образцов риса с разной архитектоникой растений при возАушной засухе

\section{А. О. Князева, Н. В.Чернышева}

Влияние обработки семян и растений риса гуминовыми препаратами

на урожайность и качество зерна

\section{И. Е. Белоусов}

Эффективность некорневой поАКормКи молибАеном на сортах, различающихся требовательностью и уровню азотного питания

\section{А. Я. Барчукова, Я. К. Тосунов, Н. В.Чернышева}

ВАияние некорневой поАКОРмКИ ОЗИмой пшеницы ЖИАКИм минеральным УАобрением актив марки азот на ростовые и формообразовательные процессы, урожайность и качество зерна

Е. Н. Киселев, А. В. Погорелов, С. В. Гаркуша, М. А. Скаженник, В. С. Ковалев, Е. М. Харитонов, С. В. Кизинек, В. Н. Чижиков

Исследование посевов риса в Краснодарском крае по Аанным АИстанционного зонАирования (преАварительный анализ)

\section{С. Н. БОлОтИН, Т. Ф. БочКО, А. С. ФеАЮчОК}

Исследование трансформированности почв земель сельскохозяйственного назначения методом ЭПР спектроскопии

В. Н. Паращенко, А. В. Осипов, В. Н. САюсарев, В. Н. Чижиков, И. И. Суминский ВоАно-физические свойства ал^ювиальных ^уговых и перегнойно-глеевых почв запалного преАкавказья при возАелывании риса

\section{И. В. Козлова}

В^ияние уровня минерального питания и применения полива на проАуктивность и урожайность зерновой фасоли

\section{В. Н. Чижиков, Р. С. Шарифумлин, И. В. Козлова, О. И. Слепцова}

Эффективность применения некорневых поАКормок молибАеновым и фосфорнокалийным УАобрениями при капельном поливе на посевах лущильной фасоли

\section{С. В. Королева, В. Э. Аазько, И. В. Коз^ова, О. В. Якимова, Н. В. Шуляк}

Применение мульчирующей черной полимерной биоразрушаемой пленкой фирмы

\section{О. В. Зеленская}

Сорные растения рода Lindernia ALL. на рисовых полях Краснодарского края 